\title{
(RE)POZICIONIRANJE EVROPSKE KOMISIJE NA TRŽIŠTU PRIRODNOG GASA: OD NOSIOCA LIBERALIZACIJE ENERGETSKOG TRŽIŠTA DO „EVROPSKOG REGULATORA"?
}

\begin{abstract}
Strahinja OBRENOVIĆ*
Apstrakt: U radu se razmatra pozicija Evropske komisije na tržištu prirodnog gasa, i to u razdoblju od usvajanja Prvog energetskog paketa pa sve do usvajanja trenutno važećeg, Trećeg energetskog paketa. Cilj istraživanja jeste da se analizira uloga Evropske komisije u odnosu na proces liberalizacije i integracije tržišta prirodnog gasa u Evropskoj uniji. Metode korišćene u radu se, pre svega, odnose na analizu akata sadržanih u energetskim paketima, ali i komparaciju različitih legislativnih rešenja u tri energetska paketa. U tom smislu, rad treba da pruži odgovor na pitanje da li je Evropska komisija postala novi „evropski regulator” na tržištu gasa, i to zahvaljujući ovlašćenjima koja su joj dodeljena energetskim paketima, naročito Trećim energetskim paketom. Zaključak istraživanja jeste da zakonodavac nije predvideo dodeljivanje uloge energetskog regulatora Komisiji, ali joj je dodelio dalekosežna ovlašćenja - naročito prilikom odlučivanja o izuzeću nove energetske infrastrukture. U poslednjem delu rada ukazano je i na legislativne izmene koje je Komisija inicirala, i koje idu u pravcu proširenja domena primene Trećeg energetskog paketa, samim tim snažeći dalje poziciju Komisije na energetskom tržištu.
\end{abstract}

Ključne reči: Evropska komisija, energetsko tržište, tržište prirodnog gasa, liberalizacija, regulacija, energetski paketi

\section{1) UVOD}

Energetika predstavlja jednu od najvažnijih oblasti svake države bez koje je teško zamisliti postojanje i funkcionisanje modernih država. Ova oblast je dugo bila rezervisana isključivo za nacionalne države i nije bilo regulacije na višem,

\footnotetext{
* Istraživač-pripravnik, Institut za evropske studije, Trg Nikole Pašića 11.

E-mail: strahinja.obrenovic@ies.rs.
} 
regionalnom ili globalnom nivou. To se odnosilo i na članice nekadašnje Evropske zajednice, odnosno današnje Evropske unije. Države su nastojale da zadrže isključivu nadležnost u oblasti energetike, koja se smatrala (i dalje se smatra) strateškom oblašću svake države. Aktivnost Evropske komisije (EK) usmerila se krajem osamdesetih i početkom devedesetih godina prošlog veka na uspostavljanje unutrašnjeg tržišta u sektorima električne energije i gasa, u kojima nije postojala dovoljna integrisanost nacionalnih tržišta. Uloga Komisije od početka aktivnosti u ovoj oblasti odnosila se na promovisanje liberalizacije tržišta električne energije i gasa, što je bilo u skladu sa idejom stvaranja jedinstvenog tržišta, proklamovanom Jedinstvenim evropskim aktom i koja je lansirana početkom devedesetih godina.

U nastavku rada analiziraće se tržište prirodnog gasa, dok će biti izostavljena analiza instrumenata koji regulišu tržište električne energije. Naime, i tržište električne energije i tržište prirodnog gasa su potpali pod pravni okvir tri energetska paketa, od kojih je Treći energetski paket i dalje na snazi. Ovi energetski paketi predstavljaju set pravnih instrumenata koji se odnose na tržišta električne energije i gasa. Vremenom je tzv. energetski acquis rastao, tako da danas obuhvata veliki broj odredbi primarnog i sekundarnog prava Evropske unije. Takođe, pored promocije liberalizacije energetskog tržišta, aktivnost institucija Unije usmerila se i na pitanja energetske bezbednosti, odnosno sigurnog snabdevanja energentima, ${ }^{1}$ ali sve više i pitanjem održivog razvoja i zaštite životne sredine. Kako je reč o složenoj i obimnoj materiji, predmet istraživanja je ograničen na pitanja koja su neposredno vezana za tržište prirodnog gasa i koja potpadaju pod pravni režim tri energetska paketa, iako je sama oblast energetike mnogo šira i pravila u ovoj oblasti mnogo razuđenija.

\section{2) LIBERALIZACIJA ENERGETSKOG TRŽIŠTA: NEDOSTAJUĆI DEO SLAGALICE}

Kada je reč o energetskom tržištu država članica Evropske unije, ono je dugi niz godina ostalo izvan integracionih procesa koji su išli u pravcu stvaranja unutrašnjeg, odnosno jedinstvenog evropskog tržišta. ${ }^{2}$ Države članice nisu bile

\footnotetext{
${ }^{1}$ Iako sigurnost snabdevanja (security of supply) predstavlja jednu od važnih komponenti koncepta energetske bezbednosti, treba istaći da je energetska bezbednost (energy security) kao pojam mnogo širi. Više o konceptu energetske bezbednosti u: Christian Winzer, "Conceptualizing energy security", Energy policy, Vol. 46, 2012, pp. 36-48; Aleh Cherp and Jessica Jewell, "The concept of energy security: Beyond the four As", Energy Policy, Vol. 75, 2014, pp. 415-421.

${ }^{2} \mathrm{U}$ teoriji postoji neslaganje u pogledu dihotomije jedinstveno tržište (single market) i unutrašnje tržište (internal market). Primetno je da se u izveštaju, koji je podnet predsedniku Komisije Hose Manuel Barosu (José Manuel Barroso) 2010. godine, pod nazivom A New Strategy for the Single Market at the Service of Europe's Economy and Sosiety, koristi termin
} 
spremne da prepuste svoju nadležnost u ovoj oblasti nadnacionalnim institucijama, i stoga su je „ljubomorno čuvale kao domen državnog suvereniteta". ${ }^{3}$ U posleratnom periodu dominirale su nacionalne kompanije koje su često uživale monopolski položaj na domaćem tržištu. Nije postojao interes da dođe do liberalizacije nacionalnih tržišta kojom bi se omogućilo učestvovanje većeg broja učesnika, odnosno konkurenata na tržištu. Iako je ovo bilo prepoznato kao problem od strane Komisije, energetska tržišta država članica su u velikoj meri ostala fragmentisana sve do poslednje decenije XX veka.

Nagoveštaj moguće promene na energetskom tržištu Unije usledio je nakon što su otpočeta dva procesa: prvo, proces liberalizacije koji otpočeo u Sjedinjenim Američkim Država i Ujedinjenom Kraljevstvu, i to nakon što su na vlast došle (neo)konzervativne političke stranke, i drugi faktor se odnosio na lansiranje ideje jedinstvenog evropskog tržišta koje je trebalo da zaživi početkom devedesetih godina XX veka. Ovi procesi su trebali da doprinesu jačanju pozicije Komisije, koja je sve vreme nastojala da pokrene pitanje liberalizacije energetskih tržišta članica i da podstakne kreiranje jedinstvenog energetskog tržišta na nivou Unije.

Postepena liberalizacija energetskog tržišta u Sjedinjenim Državama i Ujedinjenom Kraljevstvu pokazala je pozitivne efekte u pogledu veće konkurencije i ulaska novih igrača na tržište, što je u velikoj meri uticalo da se ovo pitanje razmotri i na nivou Unije krajem osamdesetih, odnosno početkom devedesetih godina prošlog veka. ${ }^{4}$ Od većeg značaja za jačanje pozicije Komisije u energetskom sektoru bila je ideja o jedinstvenom evropskom tržištu. Predsednik komisije Žak Delor (Jacques Delors), zajedno sa komesarom zaduženim za oblast unutrašnjeg tržišta Lordom Kokfildom (Lord Cockfield), lansirao je sredinom osamdesetih godina projekat jedinstvenog tržišta, i predstavio je Belu knjigu o „dovršavanju unutrašnjeg tržišta" (White paper on "Completing the Internal Market") Evropskom savetu u Milanu 1985. godine. Jedinstvenim evropskim aktom (SEA - Single European Act)

single market, za razliku od drugih dokumenata Unije gde se upotrebljava termin internal market. Autori izveštaja smatraju da je pogodnije koristiti termin jedinstveno tržište, i to iz tri razloga - unutrašnje tržište može da asocira na metaforu o „Evropi kao tvrđavi” fortress Europe); svako tržište pojedinačne članice Unije je unutrašnje i stoga treba govoriti o jedinstvenom tržištu koje treba da prevaziđe fragmentisanost; i upotreba termina unutrašnje tržište može kod građana Unije da stvori zabunu da je reč o domaćem, odnosno nacionalnom tržištu. Videti: “A New Strategy for the Single Market at the Service of Europe's Economy and Society", Report to the President of the European Commission José Manuel Barroso By Mario Monti, 9 May 2010, p. 13.

${ }^{3}$ Anna Herranz-Surrallés, Israel Solorio and Jenny Fairbrass, "Renegotiating authority in the Energy Union: A Framework for Analysis", Journal of European Integration, Vol. 42, No. 1, 2020, p. 3.

${ }^{4}$ Kim Talus, Introduction to EU Energy Law, Oxford University Press, Oxford, 2016, p. 3. 
bilo je previđeno dovršavanje unutrašnjeg tržišta, i to je trebalo da se desi početkom devedestih godina, odnosno govorilo se o 1992. godini kao ciljnoj. Dilema se javila u pogledu toga da li energetsko tržište predstavlja sastavni deo unutrašnjeg tržišta, što je proizvelo nesaglasnost među institucijama Unije (naročito Komisijom) i pojedinim članicama. ${ }^{5}$ Pitanje je bilo kompleksno jer se neposredno odnosilo i na obim ovlašćenja Komisije u oblasti energetike, tj. energetskog tržišta.

Među državama koje su se protivile jačanju ovlašćenja Evropske komisije na energetskom tržištu nalazile su se Nemačka i Francuska. ${ }^{6}$ Bez podrške ključnih članica Unije nije bilo moguće preduzeti radikalnije mere koje bi vodile stvaranju jedinstvenog energetskog tržišta. Komisija je već 1992. godine iznela predlog direktiva koje bi se odnosile na unutrašnje tržište električne energije i prirodnog gasa, a među najvažnijim predlozima su se već tada našle tri tačke koje su se odnosile na:

- transparentnost i nediskriminaciju u delatnosti proizvodnje električne energije i izgradnje infrastrukture;

- razdvajanje (unbundling) delatnosti proizvodnje, transporta i distribucije kod vertikalno integrisanih privrednih subjekata;

- pristup treće strane (TPA - third party access) mrežama. ${ }^{7}$

Ovi predlozi su predstavljali ambiciozan pristup Evropske komisije regulaciji energetskog tržišta na evropskom nivou. Pored država koje smo prethodno pomenuli, čak je i Evropski parlament u svom mišljenju dao drugačije viđenje kako treba da se kreira zajedničko energetsko tržište. ${ }^{8}$ Evropska komisija nije odustala od prvobitnog cilja da se postigne jedistveno evropsko tržište električne energije i gasa, ali je prihvatila da se do tog cilja dolazi postepeno, odnosno etapno. Sekundarni izvori prava bili su neophodni kako bi se regulisale specifičnosti vezane za tržište električne energije i gasa, kao što su zavisnost od mreža, odnosno infrastrukture prilikom njihovog transporta. ${ }^{9}$ Problem je bio što sve do Lisabonskog

\footnotetext{
${ }^{5}$ Evropska komisija, odnosno tadašnja Komisija Evropskih zajednica, je već 1988. godine predstavila radni dokument pod nazivom „Unutrašnje energetsko tržište”, u kome se navodi da energetsko tržište predstavlja deo unutrašnjeg tržišta koje je trebalo dovršiti 1992. godine. U pomenutom dokumentu se detaljnije analiziraju tržišta različitih izvora energije i njihove specifičnosti - uglja, nafte, prirodnog gasa, nuklearne energije, ali i tržišta električne energije. Videti više: "The Internal Energy Market", Commission Working Document, Commission of the European Communities, COM (88) 238 Final, Brussels, 2 May 1988.

${ }^{6}$ Claus-Dieter Ehlermann, "Role of the European Commission as Regards National Energy Policies", Journal of Energy \& Natural Resources Law, Vol. 12:3, pp. 344-345.

${ }^{7}$ Ibidem, pp. 342-343.

${ }^{8}$ Nicole Herveg, European Union Policy-Making: The Regulatory Shift in Natural Gas Market Policy, International Series on Public Policy, Palgrave Macmillan, 2017, p. 116.

${ }^{9}$ Tržišta električne energije i gasa predstavljaju tzv. network-bound sectors, odnosno sektore čije funkcionisanje zavisi od dostupnosti mreža za prenos ili transport električne energije i gasa.
} 
ugovora, kao primarnog izvora prava EU, nije postojao član koji bi se isključivo odnosio na oblast energetike, iako su pojedini aspekti energetike bili predmet ineteresovanja još od ugovora kojim je formirana Evropska zajednica za ugalj i čelik.

\section{3) POJAČANI AKTIVIZAM EVROPSKE KOMISIJE - PRVI I DRUGI ENERGETSKI PAKET}

Aktivnosti Evropske komisije u pogledu liberalizacije energetskog tržišta su intenzivirane u drugoj polovini devedesetih godina. Jedan od značajnijih koraka bilo je usvajanje tzv. Prvog energetskog paketa, odnosno Direktive o zajedničkim pravilima na tržištu električne energije 1996. godine i Direktive o zajedničkim pravilima na tržištu prirodnog gasa 1998. godine. Kao što se može primetiti, energetskim paketima se regulišu sektori električne energije i prirodnog gasa. Takođe, može se uočiti da je direktiva koja se odnosi na tržište gasa usvojena dve godine nakon direktive koja reguliše tržište električne energije. To je bila posledica teških pregovora koji su vođeni između ključnih članica Unije i Komisije, pri čemu je najviše sporenja izazvao zahtev koji se odnosio na pristup treće strane (TPA) mrežama. ${ }^{10}$

Direktiva o zajedničkim pravilima za unutrašnje tržište prirodnog gasa iz 1998. godine, predstavljala je početni uspeh Evropske komisije - da se podstakne liberalizacija i integracija tržišta gasa. Ipak, Komisija je morala da pristane na određene ustupke kako bi privolela pojedine ključne članice da prihvate predlog liberalizacije tržišta gasa. Prihvaćen je model razdvajanja računa (account unbundling), ali ne i prvobitni predlog pravnog razdvajanja (legal unbundling), kod vertikalno integrisanih preduzeća za različite delatnosti u sektoru gasa. ${ }^{11}$ Druga značajna odredba Direktive, koja je takođe rezultat kompromisa, odnosi se sa na uvođenje pregovaranog (negotiated access) i regulisanog pristupa (regulated access) treće strane mrežama, odnosno postrojenjima u sektoru gasa. Uočljivo je da su ovakva rešenja predstavljala značajno odstupanje od prvobitnog nacrta direktive iz 1992. godine. U ovom razdoblju došlo je i do stupanja na snagu sporazuma iz Mastrihta 1993. godine, koji je uneo značajne novine, od kojih je za ovu analizu

Doduše, ekspanzijom tečnog prirodnog gasa (LNG - liquefied natural gas) javlja se tendencija smanjene zavisnosti prenosa gasa cevovodima, ali i dalje postoji zavisnost od infrastrukture poput terminala, odnosno postrojenja za likvefakciju i regasifikaciju. Slične (network-bound) karakteristike su prisutne i u drugim sektorima, poput železnica i telekomunikacija. Videti više: Piet Jan Slot and Andrew Skudder, "Common features of community law regulation in the network-bound sectors", Common Market Law Review, Vol. 38, 2001, pp. 87-129.

${ }^{10}$ Jonathan P. Stern, Competition and Liberalization in European Gas Markets: a Diversity of Models, Royal Institute of International Affairs, London, Washington, DC: Brookings Institution, 1998, pp. 94-98.

${ }^{11}$ Videti Tabelu 1 u nastavku teksta. 
važna ona koja se odnosila na jačanje pozicije Evropskog parlamenta (EP) u procesu odlučivanja. To je značilo da Komisija mora pored Saveta istovremeno da privoli i članove EP za svoj predlog liberalizacije tržišta električne energije i gasa. Usvajanje direktive o zajedničkim pravilima za unutrašnje tržište prirodnog gasa je u velikoj meri olakšano nakon što je usvojena slična Direktiva za tržište električne energije, čime se može napraviti paralela sa onim što Kingdon (John W. Kingdon) naziva „prelivanjem” (spillover), odnosno kada se uspeh iz jedne oblasti politike „preliva” u drugu sličnu oblast. ${ }^{12}$

\section{Tabela 1: Modeli razdvajanja kod vertikalno integrisanih preduzeća}

\begin{tabular}{|l|l|}
\hline $\begin{array}{l}\text { razdvajanje računa } \\
\text { (account unbundling) }\end{array}$ & $\begin{array}{l}\text { podrazumeva vođenje zasebnih računa za svaku od } \\
\text { delatnosti (prenosa i distribucije odvojeno od proizvodnje } \\
\text { i snabdevanja) vertikalno integrisanog preduzeća. }\end{array}$ \\
\hline $\begin{array}{l}\text { funkcionalno razdvajanje } \\
\text { (functional unbundling) }\end{array}$ & $\begin{array}{l}\text { polazeći od razdvajanja računa za svaku od delatnosti, } \\
\text { zahteva se i organizaciono razdvajanje sa izvesnim stepenom } \\
\text { autonomnosti (pre svega ljudske, materijalne, tehničke) u } \\
\text { odnosu na ostatak vertikalno integrisanog preduzeća. }\end{array}$ \\
\hline $\begin{array}{l}\text { pravno razdvajanje } \\
\text { (legal unbundling) }\end{array}$ & $\begin{array}{l}\text { podrazumeva osnivanje posebnih pravnih subjekata, } \\
\text { odnosno pravno razdvajanje mrežnih delatnosti od ostalih } \\
\text { delatnosti kompanije, koja obavlja delatnost proizvodnje i i } \\
\text { snabdevanja. }\end{array}$ \\
\hline $\begin{array}{l}\text { vlasničko razdvajanje } \\
\text { (ownership unbundling) }\end{array}$ & $\begin{array}{l}\text { najrigorozniji, odnosno najzahtevniji model razdvajanja } \\
\text { koji podrazumeva da vlasnik prenosnog sistema ne može } \\
\text { istovremeno da bude vlasnik kompanije koja obavlja } \\
\text { delatnost proizvodnje i snabdevanja. }\end{array}$ \\
\hline $\begin{array}{l}\text { nezavisni operator sistema } \\
\text { (ISO - independent operator } \\
\text { of system) }\end{array}$ & $\begin{array}{l}\text { omogućava da vertikalno preduzeće zadrži vlasništvo nad } \\
\text { prenosnim sistemom, ali se upravljanje i svakodnevne } \\
\text { aktivnosti poveravaju nezavisnom operatoru sistema. }\end{array}$ \\
\hline $\begin{array}{l}\text { nezavisni operator } \\
\text { prenosnog sistema } \\
\text { (TTO - independent } \\
\text { transmission operator) }\end{array}$ & $\begin{array}{l}\text { pod ovim modelom operator ostaje u sastavu vertikalno } \\
\text { integrisanog preduzeća, ali se predviđaju brojni uslovi i i } \\
\text { obaveze kako bi se postigla nezavisnost operatora u radu. }\end{array}$ \\
\hline
\end{tabular}

${ }^{12}$ John W. Kingdon, Agendas, alternatives, and public policies, Boston: Little, Brown, 1984, p. 184. Treba napomenuti da termin, odnosno koncept „prelivanja” (spillover) predstavlja višeznačan pojam u društvenim naukama, te da značenje koje mu pripisuje Kingdon nije jedino. Tako je, na primer, koncept spillover-a popularizovan od strane politikologa Ernsta Hasa (Ernst Haas) i neofunkcionalističke struje u polju evropskih studija. Videti više: Dejana Vukčević i Miša Stojadinović, „Proces proširenja EU: koncept 'prelivanja”, Srpska politička misao, broj 4, Vol. 34, 2011, str. 131-152. 
Nakon što je usvojena Direktiva 1998. godine u sektoru gasa, bilo je jasno da je proces liberalizacije tržišta prirodnog gasa tek otpočeo. Pomenuta Direktiva nije dodelila značajnija ovlašćenja Komisiji na energetskom tržištu, ali je ona postala još aktivnija u pogledu izgradnje unutrašnjeg energetskog tržišta. U posebnom članu Direktive iz 1998. godine predviđena je mogućnost unapređenja pravnog i regulatornog okvira na osnovu iskustva stečenog tokom primene Direktive i funkcionisanja energetskog tržišta, i o tome Evropska komisija izveštava Savet i Evropski parlament. ${ }^{13}$

Komisija je već 2000 . godine vratila pitanje liberalizacije tržišta gasa na agendu, jer je zaključeno da postojeći instrumenti nisu dovoljni, i već naredne godine predložila novi paket instrumenata. Za razliku od devedesetih godina, okolnosti su sada bile povoljnije za aktivizam Komisije na polju liberalizacije i integracije energetskog tržišta usled postepenog prihvatanja ideje liberalizacije energetskog tržišta od strane većine država članica Unije. Ipak, i dalje su se pojedine države protivile pojedinim predlozima u pogledu liberalizacije tržišta. Tako se, na primer, Francuska opirala otvaranju svog energetskog tržišta i modelu pravnog razdvajanja (legal unbundling) kod vertikalno integrisanih preduzeća, dok se Nemačka protivila predlogu da se uspostavi nacionalno regulatorno telo (NRA - National Regulatory Authority) na njenom enegetskom tržištu. ${ }^{14}$ Pregovori koji su prethodili usvajanju Drugog energetskog paketa trajali su znatno kraće u odnosu na pregovore koji su prethodili usvajanju Prvog energetskog paketa. Nova Direktiva u sektoru prirodnog gasa usvojena je 2003. godine, dok je 2005. usvojena Uredba o uslovima pristupa prenosnim mrežama na tržištu gasa.

Drugi energetski paket doneo je značajne novine u oblasti tržišta prirodnog gasa. Jedna od bitnih izmena odnosila se na usvajanje modela funkcionalnog razdvajanja (functional unbundling), odnosno pravnog razdvajanja (legal unbundling) kod vertikalno integrisanih privrednih subjekata u sektoru gasa, dok ambiciozniji cilj vlasničkog razdvajanja (ownership unbundling) nije uvršten u konačni tekst Direktive usled protivljenja jednog broja članica. Druga bitna promena je načinjena kod pristupa treće strane sistemu gde se, za razliku od Prvog energetskog paketa koji prihvata pregovarani i regulisani pristup, prihvata samo regulisani pristup treće strane na bazi unapred objavljenih tarifa i uslova koji se bez diskriminacije primenjuju na sve korisnike. ${ }^{15}$ Takođe, prema Drugom

${ }^{13}$ Article 28, "Directive 98/30/EC of the European Parliament and of the Council of 22 June 1998 concerning common rules for the internal market in natural gas", Official Journal L 204, 21 July, 1998.

${ }^{14}$ Nicole Herveg, European Union Policy-Making: The Regulatory Shift in Natural Gas Market Policy, op. cit., p. 167.

${ }^{15}$ Article 18, "Directive 2003/55/EC of the European Parliament and of the Council of 26 June 2003 concerning common rules for the internal market in natural gas and repealing Directive 98/30/EC", Official Journal L 176, 15 July 2003. 
energetskom paketu članice Unije treba da uspostave regulatorna tela (NRA national regulatory authority) koja treba da doprinesu uspostavljanju funkcionalnog energetskog tržišta.

Pozicija Komisije na tržištu prirodnog gasa je dodatno ojačana, što je potvrđeno većim brojem odredbi iz Direktive i Uredbe u sklopu Drugog energetskog paketa. Naime, države članice treba da informišu Komisiju o svim preduzetim merama u pogledu ispunjavanja obaveze javne usluge (PSO - public service obligation), ${ }^{16}$ dok slična obaveza postoji i kod preuzimanja mera zaštite (safeguard measures) od strane članica, koje treba da obaveste Komisiju i druge članice Unije. ${ }^{17}$ Možda najznačajnije ovlašćenje dodeljeno Komisiji vezano je za dodeljivanje izuzeća u pogledu nove (energetske) infrastrukture. Države članice, odnosno njena relevantna tela, koja odlukom dodeljuju izuzeće pojedinoj novoj glavnoj infrastrukturi (new infrastructure) od primene pojedinih odredbi Drugog energetskog paketa, treba da „bez odlaganja informišu Komisiju, zajedno sa svim relevantnim informacijama u vezi sa odlukom" ${ }^{18}$ Komisija ima pravo da „u roku od 2 meseca od prijema notifikacije zahteva da regulatorno telo ili država članica izmeni ili povuče odluku kojom se dodeljuje izuzeće". ${ }^{19}$ Takođe, obaveza notifikacije od strane država članica, odnosno njenih regulatornih tela, predviđena je i drugim odredbama direktive, poput one o derogaciji u odnosu na obavezu „uzmi ili ostavi” (take-or-pay), ili derogacije u slučaju tržišta u nastajanju, odnosno izolovanih tržišta (emergent and isolated market). Nacionalna regulatorna tela su, takođe, obavezana odredbama Direktive na saradnju sa Evropskom komisijom.

\section{4) ŠTA JE PRETHODILO TREĆEM ENERGETSKOM PAKETU?}

Usvajanje Drugog energetskog paketa nije dovelo do integracije nacionalnih energetskih tržišta u jedinstveno evropsko tržište. Komisija je prilikom evaluacije postignutog na energetskom tržištu ustanovila da, uprkos postignutom uspehu u izgradnji zajedničkog tržišta, i dalje postoji prostor za napredak. Period koji je prethodio usvajanju Trećeg energetskog paketa obeležen je značajnim promenama, kako unutar Unije tako i na globalnom tržištu gasa. Novina koja je imala značajnih posledica na energetsko tržište bilo je proširenje Evropske unije - kada je 2004. godine pristupilo deset novih članica. Energetska tržišta novih članica su se bitno

\footnotetext{
${ }^{16}$ Ibid., Article 3.

${ }^{17}$ Ibid., Article 26.

${ }^{18}$ Ibid., Article 22, para. 4.

${ }^{19}$ Ibid., Article 22. Istim članom je predviđeno da se rok od dva meseca može produžiti za još jedan mesec ukoliko su potrebne dodatne informacije Komisiji. Ukoliko država članica ili njeno regulatorno telo ne postupi po zahtevu Komisije da se odluka o izuzeću izmeni ili povuče, konačna odluka se donosi prema proceduri na koju upućuje član 30 (2) Direktive.
} 
razlikovala od tržišta zapadnoevropskih zemalja, i njih su odlikovala velika zavisnost od jednog snabdevača gasom, nedostatak interkonekcije i fragmentisanost.

Pitanje energetskog tržišta je vraćeno na agendu nakon što je na čelo Komisije došao Manuel Baroso (José Manuel Barroso). Pored proširenja Unije, pitanje energetike je intenzivirano gasnom krizom iz 2006. godine, koja je nastala usled spora ruske i ukrajinske strane. U ovom periodu Komisija je, umesto isključivog oslanjanja na predlaganje legislativnih propisa, aktivnost usmerila ka korišćenju različitih vidova „mekog prava, poput zelenih knjiga, belih knjiga, komunikacija kao sredstava za kreiranje politika". ${ }^{20}$ Primetno je da nakon usvajanja Drugog energetskog paketa dolazi do razmatranja obuhvatne energetske politike, koja je prethodnih godina bila usmerena pretežno na energetsko tržište, dok su sada sve značajnije druge komponente - sigurnost (snabdevanja) i održivost. U tom smislu je došlo do razmimoilaženja među onima koji su smatrali da tržište može da obezbedi i doprinese sigurnosti snabdevanja i održivosti, i onih koji su smatrali da isključivo oslanjanje na tržišne snage ne može da doprinese ostvarivanju ostalih komponenti energetske politike. ${ }^{21}$

Savet je već 2007. godine pozvao Komisiju da razmotri naredne korake u pogledu nove legislative koja bi se odnosila na oblast energetike. Pregovori su ovoga puta usložnjeni usled proširenja Unije, ali je olakšavajuća okolnost bila rasprostranjeno mišljenje među različitim akterima o neophodnosti preduzimanja novih mera u oblasti energetike. Mnogi autori smatraju da je aktivnost Komisije olakšana kada je otvoren „prozor šanse” (window of opportunity). ${ }^{22}$ Postoji neslaganje kada je reč o događajima koji su doprineli da se „prozor šanse” otvori. Dok jedni autori smatraju da je do razvoja energetske politike došlo nakon proširenja Unije 2004. godine i narednih godina, drugi su skloni mišljenju da su gasne krize iz 2006, i naročito 2009. godine, doprinele intenziviranju aktivnosti Komisije u ovoj oblasti. ${ }^{23} \mathrm{U}$ radu se zastupa stav da ova dva događaja ne treba

\footnotetext{
${ }^{20}$ Jan Frederik Braun, "Multiple Sources of Pressure for Change: The Barroso Commission and Energy Policy for an Enlarged EU”, Journal of Contemporary European Research, Vol. 5, Issue 3, p. 430.

${ }^{21}$ Francis McGowan, “Can the European Union's Market Liberalism Ensure Energy Security in a Time of 'Economic Nationalism'?", Journal of Contemporary European Research, Vol. 4, No. 2, p. 91.

${ }^{22}$ Tomas Maltby, "European Union energy policy integration: A case of European Commission policy entrepreneurship and increasing supranationalism”, Energy Policy, Vol. 55, 2013, pp. 438-440.

${ }^{23}$ Ovde su pomenuti samo neki od događaja koji su uticali na razvoj energetske politike Evropske unije. Njima treba pridodati i neke druge faktore, poput sveukupnih odnosa Evropske unije i država izvoznica energenata, naročito Rusije. Videti više u: Nevena Šekarić, „Sekuritizacija energetskih odnosa između Evropske unije i Rusije: evropska perspektiva”, Međunarodna politika, br. 1176, 2019, pp. 63-82.
} 
posmatrati kao potpuno izolovane, baš kao što autor Mišik (Matúš Mišík) ukazuje da je proširenje Unije, koje je usledilo 2004. godine (i kasnijih godina), imalo velikog uticaja na intenzitet gasne krize 2009. godine, jer su istočne članice Unije ujedno bile među najpogođenijim. ${ }^{24}$

Kada je reč o pregovorima koji su prethodili usvajanju Trećeg energetskog paketa 2009. godine, jedno od spornih pitanja bio je konačni model razdvajanja kod vertikalno integrisanih preduzeća. Među državama članicama bile su suprotstavljene dve grupacije - jedna koja je podržavala predlog Komisije da se usvoji model vlasničkog razdvajanja (ownership unbundling), koji je trebao da doprinese unapređenju konkurentnosti na energetskom tržištu, i onih članica koje su smatrale da bi takav model bio suprotan njihovim energetskim interesima i ciljevima. Goldtau (Andreas Goldthau) i Siter (Nick Sitter) ističu da je Evropska komisija „ostala liberalni akter čak i kada je svet napustio benigno protržišno okruženje iz devedesetih godina i postao više merkantilistički - ili realistički". 25 Nemačka je bila među zemljama koje su se protivile ambicioznom modelu vlasničkog razdvajanja, dok su sličan stav zauzele i Francuska, Austrija, Kipar, Grčka, Bugarska, Luksemburg i Slovačka. Kao pobornici modela vlasničkog razdvajanja istakli su se Ujedinjeno Kraljevstvo, Holandija, Belgija, Švedska, Danska, Finska, Španija i Rumunija. ${ }^{26}$ Pitanje je naročito bilo delikatno za Nemačku jer je započela novu fazu saradnje sa ruskom stranom, koja je zamajac doživela izgradnjom gasovoda Severni tok. Takođe, treba dodati i veliki broj ruskih ulaganja na većem broju energetskih tržišta država članica, koja bi mogla da potpadnu pod restriktivniji režim predloženog Trećeg energetskog paketa i time dovedu do mogućeg narušavanja odnosa sa Rusijom u oblasti energetike.

Evropska komisija je u svom predlogu iznela dva modela organizovanja operatora sistema - jedan je podrazumevao vlasničko razdvajanje kao „najstrožiji” model razdvajanja kod vertikalno integrisanog preduzeća, i drugi model se odnosio na uspostavljanje nezavisnog operatora sistema (ISO - independent system operator). ${ }^{27}$ Za Nemačku su ovi predlozi bili neprihvatljivi, te se ona sa jednim brojem članica zalagala za usvajanje treće varijante organizovanja operatora sistema. Obe strane su bile spremne na kompromis kako bi došlo do usajanja nove legislative, i u poslednjem trenutku je dogovoren treći model - nezavisnog

\footnotetext{
${ }^{24}$ Matúš Mišík, External Energy Security in the European Union: Small Member States' Perspective, Routledge Advances in European Politics, Taylor \& Francis Inc, Bosa Roca, 2019, p. 87.

${ }^{25}$ Andreas Goldthau and Nick Sitter, "A liberal actor in a realist world? The Commission and the external dimension of the single market for energy", Journal of European Public Policy, Vol. 21, No. 10, 2014, p. 1452.

${ }^{26}$ Nicole Herveg, European Union Policy-Making: The Regulatory Shift in Natural Gas Market Policy, op. cit., p. 212.

${ }^{27}$ Videti Tabelu 1.
} 
operatora prenosnog sistema (ITO - independent transmission operator). Zahvaljujući ovom kompromisu otvoren je put usvajanju novog legislativnog okvira, odnosno Trećeg energetskog paketa 2009. godine.

\section{5) TREĆI ENERGETSKI PAKET I KOMISIJA KAO „EVROPSKI REGULATOR"?}

Pozicija Evropske komisije u oblasti energetske politike je dodatno učvršćena usvajanjem Trećeg energetskog paketa. Lako se uočava da je ovaj energetski paket mnogo obimniji i sadržajniji u odnosu na prethodna dva. Obaveza notifikacije i informisanja Komisije od strane država članica sadržana je u većem broju odredbi Direktive 2009/73/EC. Za razliku od prethodna dva energetska paketa, energetski paket iz 2009. godine značajnu pažnju posvećuje pitanju sigurnosti snabdevanja gasom, što je u velikoj meri posledica gasne krize koja se desila krajem 2008. i početkom 2009. godine. Tako član 5 Direktive 2009/73/EC predviđa da države članice prate sigurnost snabdevanja gasom i sastavljaju godišnji izveštaj o snabdevanju gasom, koji sadrži sve mere koje su preduzete ili ih tek treba preduzeti, i taj izveštaj države prosleđuju Komisiji. ${ }^{28}$ Takođe, prema članu 8 regulatorna tela država članica treba da o svim tehničkim pravilima obaveštavaju Komisiju, pri čemu ova pravila služe kako bi se obezbedila interoperabilnost sistema.

Dalekosežne izmene su načinjene u pogledu modela organizovanja operatora gasnog sistema. Prethodno smo pomenuli da je u ovom energetskom paketu prihvaćen model vlasničkog razdvajanja (OU) kod vertikalno integrisanih preduzeća, dok su opciono ostavljeni modeli nezavisnog operatora sistema (ISO) i nezavisnog operatora prenosnog sistema (ITO). Ipak, države članice nisu u potpunosti slobodne da izaberu između ova tri modela. Obaveza vlasničkog razdvajanja je postavljena kao pravilo, dok se države članice mogu opredeliti za imenovanje nezavisnog operatora sistema ili nezavisnog operatora prenosnog sistema ukoliko do 3. septembra 2009. godine transportni sistem pripada vertikalno integrisanom preduzeću. ${ }^{29} \mathrm{U}$ članu 10 Direktive detaljnije je regulisano pitanje imenovanja i sertifikacije operatora prenosnog sistema, pri čemu „,izričitu ili prećutnu odluku o sertifikaciji operatora prenosnog sistema regulatorno telo bez odlaganja saopštava Komisiji, zajedno sa svim odgovarajućim informacijama u pogledu te odluke". ${ }^{30}$ Evropska komisija može da zahteva i sve informacije od operatora prenosnog sistema, koje su povezane sa zadacima koje Komisija izvršava.

\footnotetext{
28 "Directive 2009/73/EC of the European Parliament and of the Council of 13 July 2009 concerning common rules for the internal market in natural gas and repealing Directive 2003/55/EC", Official Journal L 211, 14 August, 2009, Article 5.

${ }^{29}$ Ibid., Article 9, para. 8 and 9.

${ }^{30}$ Ibid., Article 10, para. 6.
} 
Kada je reč o sertifikaciji u vezi sa trećim zemljama, regulatorno telo je u obavezi da o tome obavesti Komisiju. Regulatorno telo dobija mišljenje Komisije u pogledu sertifikacije u vezi sa trećim zemljama, i prilikom donošenja konačne odluke ono „vodi što je više moguće računa o mišljenju Komisije”. ${ }^{11}$ To mišljenje se objavljuje naposletku zajedno sa konačnom odlukom.

Jedna od glavnih dilema koja je bila prisutna i pre usvajanja Drugog energetskog paketa, odnosila se na pitanje energetskog regulatora na evropskom nivou. Najveći broj članica je optirao za uvođenje nacionalnog regulatornog tela, dok je manji deo podržao uvođenje evropskog regulatornog tela. ${ }^{32}$ Prethodno smo pomenuli da su pojedine članice čak oklevale da uspostave nacionalna regulatorna tela u oblasti energetike, tvrdeći da to ne bi bilo u skladu sa njihovom pravnom tradicijom i karakteristikama regulatornog sistema. Nemačka je bila među državama koje su relativno kasno uvele regulatorno telo u oblasti električne energije i gasa, pa je tako Federalna mrežna agencija (Bundesnetzagentur) dobila ovlašćenja u oblasti energetike tek 2005. godine. Regulatorno telo u Nemačkoj se najpre zvalo Regulatorno telo za telekomunikacije i poštu (Regulierungsbehörde für Telekommunikation und Post), a kada je odlučeno da se unapredi konkurentnost na tržištima železnice i energetike, i da se proširi krug zadataka koji se poverava ovom telu, naziv je promenjen u Federalna mrežna agencija za električnu energiju, gas, telekomunikacije, poštu i železnice (Bundesnetzagentur für Elektrizität, Gas, Telekommunikation, Post und Eisenbahnen). Na osnovu pravila sadržanih u energetskom paketu, sve članice su u obavezi da uspostave regulatorno telo za tržište električne energije i gasa.

Treći energetski paket je doneo značajne izmene u pogledu delovanja regulatornih tela u Evropskoj uniji. Ove izmene se mogu posmatrati na dva nivoa kroz jačanje pozicije Komisije u postupcima dodeljivanja izuzeća kod nove energetske infrastrukture i kroz oblikovanje saradnje nacionalnih regulatornih tela u okviru Agencije za saradnju energetskih regulatora (ACER - Agency for the Cooperation of Energy Regulators).

Kada je reč o novoj gasnoj infrastrukturi, predviđeno je da se u određenim slučajevima, kada su ispunjeni uslovi pobrojani članom 36 Direktive 2009/73/EC, može na određeni period dodeliti izuzeće od primene pojedinih odredbi Direktive. Ovde se može uočiti značajna razlika u pogledu člana kojim se dodeljuje izuzeće novoj gasnoj infrastrukture kod Drugog i Trećeg energetskog paketa. Potonjim je značajno ojačana pozicija Komisije, kojoj regulatorno telo „bez odlaganja dostavlja primer svakog zahteva za izuzeće, kada ga zaprimi" ${ }^{33}$ Uočljivo je da je regulatorno

${ }^{31}$ Ibid., Article 11.

${ }^{32}$ Nicole Herveg, European Union Policy-Making: The Regulatory Shift in Natural Gas Market Policy, op. cit., p. 161.

${ }^{33}$ Article 36, para. 8, "Directive 2009/73/EC of the European Parliament and of the Council of 13 July 2009 concerning common rules for the internal market in natural gas and repealing Directive 2003/55/EC", Official Journal L 211, 14 August, 2009. 
telo u obavezi da dostavi primer zahteva za izuzeće Komisiji i pre nego što donese odluku o izuzeću, što se razlikuje od rešenja iz Drugog energetskog paketa, gde je regulatorno telo obaveštavalo Komisiju nakon donete odluke. Najzad, kada regulatorno telo donese odluku, ono tu odluku „bez odlaganja saopštava Komisiji”. Komisija nakon toga može, u roku od dva meseca, da zahteva od regulatornog tela da tu odluku izmeni ili povuče, te se taj rok može produžiti za isti taj period ako Komisija zahteva dodatne informacije. ${ }^{34}$ Interesantno je da isti stav člana 36 predviđa mogućnost da se „početno razdoblje od dva meseca može produžiti i uz zajednički pristanak Komisije i regulatornog tela". ${ }^{35}$ Iz samog člana nije jasno na koji period se produžava početno razdoblje od dva meseca, što može da predstavlja pravnu prazninu i dovede do prolongiranja odluke o izuzeću. Ipak, najznačajnija novina koja je uvedena članom 36 Direktive 2009/73/EC jeste da „regulatorno telo postupa u skladu sa odlukom Komisije o izmeni ili povlačenju odluke o izuzeću u roku od mesec dana i o tome obaveštava Komisiju". ${ }^{36}$ To praktično znači da Komisija ima „poslednju reč” kada se odlučuje o izuzeću nove gasne infrastrukture, što otvara pitanje da li je Komisija novi „evropski regulator”?

Treba odmah istaći da Treći energetski paket nije predvideo da Komisija preuzme ulogu evropskog regulatora u oblasti energetike. Sadržina člana 36 Direktive 2009/73/EC da nacionalno regulatorno telo „postupa u skladu sa odlukom Komisije", može uslovno da se tumači kao dodeljivanje regulatornih ovlašćenja Komisiji u pogledu odlučivanja o izuzeću kod nove gasne infrastrukture, iako Komisija formalno ne donosi konačnu odluku. Umesto dodeljivanja regulatornih ovlašćenja Komisiji, ili formiranja novog evropskog regulatornog tela, Treći energetski paket je predvideo osnivanje Agencije za saradnju energetskih regulatora (ACER). ${ }^{37}$ Iz samog naziva agencije se može zaključiti da se ne radi o jedinstvenom evropskom regulatoru, već da je naglasak na saradnji (nacionalnih) regulatornih tela. Agencija poseduje svojstvo pravnog lica i jedan od osnovnih zadataka jeste da koordinira rad nacionalnih regulatornih tela, i stoga ne predstavlja zamenu za nacionalne regulatore, već predstavlja komplementarno telo. Samo uspostavljanje Agencije, njen pravni status, zadaci i finansiranje su precizinije određeni Uredbom o uspostavljanju ovog tela. ${ }^{38}$ Komisija, Agencija i države članice,

\footnotetext{
${ }^{34}$ Ibid., Article 36, para. 9.

${ }^{35}$ Ibid.

${ }^{36}$ Ibid.

37 "Regulation (EC) No 713/2009 of the European Parliament and of the Council of 13 July 2009 establishing an Agency for the Cooperation of Energy Regulators", Official Journal L 211, 14 August, 2019.

${ }^{38}$ Treba napomenuti da je Uredba 713/2009 o osnivanju Agencije za saradnju energetskih regulatora iz 2009. godine zamenjena novom Uredbom 2019/942 iz 2019. godine, kojom je donekle osnažena pozicije ove Agencije, i kojoj su dodeljene nove funkcije. Videti: "Regulation
} 
odnosno njihova regulatorna tela, međusobno sarađuju u pogledu stvaranja preduslova za efikasno funkcionisanje energetskog tržišta - što je ujedno i višedecenijski cilj Evropske komisije.

\section{6) PROŠIREN DOMEN PRIMENE TREĆEG ENERGETSKOG PAKETA - DALJE JAČANJE POZICIJE KOMISIJE?}

Aktivizam Evropske komisije na polju energetskog tržišta nije prestao ni nakon usvajanja Trećeg energetskog paketa. Pored sukcesivnog usvajanja energetskih paketa jedno od značajanijih pitanja bila je njihova implementacija u državama članicama. Pojedine članice su imale problem i prilikom implementacije pojedinih odredbi sadržanih u instrumentima Drugog energetskog paketa. ${ }^{39}$ Treći energetski paket, kao što se može uočiti iz prethodnog dela rada, uneo je dalekosežne promene na tržištima prirodnog gasa. Ipak, to nije ujedno bio i kraj sa predlozima i legislativnim rešenjima u ovoj oblasti. Predmet ovog istraživanja je ograničen na analizu tri energetska paketa u domenu tržišta prirodnog gasa, odnosno na tzv. sektorske propise (sector-specific regulation). Činjenica je da energetski acquis obuhvata daleko veći broj pravnih izvora, i pored regulisanja energetskog tržišta, reguliše i pitanja poput sigurnosti snabdevanja, investicija u infrastrukturu i održivog razvoja. Tako oblast (zaštite) konkurencije, takođe, predstavlja jedan značajan segment koji je u tesnoj vezi sa energetskim tržištem, i u okviru kog Evropska komisija poseduje značajna ovlašćenja, koja je neretko koristila radi uspostavljanja efektivne konkurencije na energetskom tržištu. Druge oblasti, u tesnoj vezi sa energetskim tržištem, odnose se na četiri slobode iz osnivačkih ugovora - za energetsko tržište naročito značajno slobodno kretanje roba, usluga i kapitala, potom oblast državne pomoći, zaštitne životne sredine i druge. Zbog obimnosti propisa koji postoje u ovoj oblasti, u nastavku će se razmotriti samo izmene koje su neposredno vezane za tržište gasa i trenutno važeći Treći energetski paket.

Kada je reč o unapređenju pravnog okvira u domenu tržišta prirodnog gasa, jedna od značajnijih debata povela se u vezi sa dometom primene pravila iz Trećeg energetskog paketa. Jedna od značajnih novina na energetskom tržištu Unije odnosila se na unapređenu saradnju Nemačke i Rusije u oblasti energetike. Gasovod Severni tok (1) pušten je u rad 2011. godine i predstavljao je realizaciju ideje ruske strane da diverzifikuje izvozne pravce prema evropskim potrošačima, i odgovori na povećanu tražnju za prirodnim gasom u Evropi. Ovaj projekat je izazvao

(EU) 2019/942 of the European Parliament and of the Council of 5 June 2019 establishing a European Union Agency for the Cooperation of Energy Regulators", Official Journal L 158, 14 June, 2019.

${ }^{39}$ Nicole Herveg, European Union Policy-Making: The Regulatory Shift in Natural Gas Market Policy, op. cit., p. 196. 
negativne reakcije od strane pojedinih članica, dok je Komisija zauzela skeptičan stav u odnosu na porast zavisnosti od uvoza gasa iz Rusije. Ipak, mnogo više kontroverzi je izazvao projekat Severni tok 2, koji treba značajno da poveća kapacitet protoka gasa sa ruske teritorije direktno u Nemačku ${ }^{40}$ Evropska komisija je bila mnogo odlučnija prilikom protivljenja ovom projektu i razmatrala je način kako da predupredi dominaciju ruskog gasa na evropskom tržištu. U nastavku rada je izostavljen čisto politički aspekt ovog pitanja, dok se bliže analiziraju legislativni predlozi Komisije koji su imali za cilj da preciziraju ili prošire (zavisno od tumačenja) polje primene pravnih akata iz Trećeg energetskog paketa.

Postojao je konsenzus da se propisi Trećeg energetskog paketa primenjuju na teritoriji članica Unije, ali se neslaganje javilo u pogledu primene istih propisa na podvodne gasovode (offshore pipeline) koji povezuju, odnosno koji će povezivati jednu od država članica i treću zemlju. Predlog Evropske komisije odnosio se na amandiranje postojeće Direktive 2009/73/EC, koja bi trebalo da se primenjuje i na delove podvodnih gasovoda koji prolaze kroz teritorijalno more (territorial sea) i isključivu privrednu zonu (exclusive economic zone) pojedinih članica Unije, ali je i iznela predlog da Komisija dobije ovlašćenje od Saveta za vođenje pregovora o snabdevanju gasom sa ruskom stranom. ${ }^{41}$ Predlog da se domen primene energetskog paketa proširi i na određene morske pojaseve država članica, zahtevalo je da se iskorači iz polja prava EU i da se konsultuju norme međunarodnog prava i to prava mora. Jedno od značajnih pitanja u odnosima među državama jeste pitanje granica, odnosno suvereniteta na određenoj teritoriji. S tim u vezi postavlja se i pitanje nadležnosti država na moru, posmatrajući različite morske pojaseve. ${ }^{42}$

Konačan tekst amandmana na Direktivu iz 2009. godine o zajedničkim pravilima za tržište prirodnog gasa, eksplicitno je predvideo da se primena tog instrumenta odnosi i na pojas teritorijalnog mora članica, ali je izostavljeno pominjanje njegove primene u isključivoj privrednoj zoni. ${ }^{43}$ Inicijalni predlog Komisije je bio da se primenom obuhvate i delovi gasovoda u isključivoj privrednoj

${ }^{40}$ Više o tome: Nevena Šekarić, „Evropska energetska bezbednost: slučaj Severnog toka 2”, Međunarodna politika, br. 1179-80, 2020, str. 119-138.

${ }^{41}$ Leigh Hancher and Anna Marhold, "A common EU framework regulating import pipelines for gas? Exploring the Commission's proposal to amend the 2009 Gas Directive", Journal of Energy \& Natural Resources Law, Vol. 37, Issue 3, 2019, pp. 289-290.

${ }^{42}$ Više o pravu mora i pravilima kojima se određuju granice na moru u: Bojan Tubić, „Međunarodna pravila o određivanju granica na moru”, Zbornik radova Pravnog fakulteta u Novom Sadu, Vol. 4, 2013, str. 337-352.

${ }^{43}$ Videti amandiranu definiciju interkonektora: Article 1, "Directive (EU) 2019/692 of the European Parliament and of the Council of 17 April 2019 amending Directive 2009/73/EC concerning common rules for the internal market in natural gas", Official Journal L 117, 3 May, 2019. 
zoni država članica, ali se od predloga odustalo jer je nadležnost obalnih država u ovoj zoni funkcionalna. ${ }^{44}$ Ipak, Komisija je ostvarila značajan uspeh nakon što su prihvaćeni amandmani na tekst Direktive iz 2009. godine. Na taj način, Komisija je pokazala da se njena aktivnost na tržištu gasa nije okončala usvajanjem Trećeg energetskog paketa, i da ona i dalje ostaje zaintresovana za konačnu integraciju nacionalnih tržišta u istinski jedinstveno energetsko tržište.

\section{7) ZAKLJUČAK}

Evropska komisija je kontinuirano radila na liberalizaciji energetskog tržišta, kako bi se ostvarilo jedinstveno, odnosno unutrašnje energetsko tržište na evropskom nivou. Njena aktivnost se ogledala u predlaganju ključnih rešenja koja su se odnosila na sektor električne energije i prirodnog gasa. Značajan korak, u tom smislu, bilo je sukcesivno usvajanje energetskih paketa koji su sačinjeni od različitih pravnih instrumenata. Pored odredbi sadržanih u energetskim paketima, Komisija se na energetskom tržištu oslanjala i na povezane oblasti, poput konkurencije, slobode kretanja robe i kapitala na tržištu, državne pomoći, zaštite životne sredine i druge. U radu su detaljnije analizirana samo ona rešenja sadržana u okviru tri energetska paketa, iako je nesporno da energetski acquis danas čine i drugi instrumenti, odnosno primarni i sekundarni izvori prava. Poređenjem tri energetska paketa mogu se uočiti dve tendencije. Jedna se odnosi na postepeno prihvatanje predloga Komisije u pogledu liberalizacije sektora prirodnog gasa, uprkos protivljenju pojedinih ključnih članica Unije. Druga tendencija se odnosi na jačanje pozicije i ovlašćenja Komisije na energetskom tržištu, što je otvorilo pitanje da li je Komisija od nosioca liberalizacije tržišta gasa postala evropski regulator na energetskom tržištu. Iako odredbe Trećeg energetskog paketa nisu predvidele dodeljivanje funkcije regulatora Evropskoj komisiji, njoj su ipak dodeljena značajna ovlašćenja koja joj omogućavaju da u određenim situacijama ima primat u odnosu na nacionalna regulatorna tela, naročito kod odlučivanja o izuzeću nove energetske infrastrukture. Pored nacionalnih regulatornih tela uspostavljena je i Agencija za saradnju energetskih regulatora, kao telo koje treba da koordinira rad nacionalnih regulatora na energetskom tržištu. Regulatorni sistem na energetskom tržištu Unije uspostavljen je na bliskoj saradnji i komplementarnosti nacionalnih regulatornih tela, Agencije za saradnju energetskih regulatora i Evropske komisije. Poslednji amandmani na Direktivu iz 2009. godine o zajedničkim pravilima za tržište prirodnog gasa, idu u pravcu proširenja domena primene energetskih pravila. To je značajan pokazatelj da je Komisija nastavila da bude aktivna kada je reč o integraciji tržišta gasa država članica i dovršavanju unutrašnjeg tržišta, te se mogu

${ }^{44}$ Leigh Hancher and Anna Marhold, "A common EU framework regulating import pipelines for gas? Exploring the Commission's proposal to amend the 2009 Gas Directive”, op. cit., p. 300. 
očekivati i nove inicijative u ovoj oblasti sve dok se ne postigne cilj i stvori funkcionalno tržište u ovom sektoru na nivou Unije.

\section{8) LITERATURA}

A New Strategy for the Single Market at the Service of Europe's Economy and Sosiety, Report to the President of the European Commission José Manuel Barroso By Mario Monti, 9 May 2010.

Braun, Jan Frederik, "Multiple Sources of Pressure for Change: The Barroso Commission and Energy Policy for an Enlarged EU", Journal of Contemporary European Research, Vol. 5, Issue 3, pp. 428-45.

Cherp, Aleh and Jewell, Jessica, "The concept of energy security: Beyond the four As", Energy Policy, 75, 2014, pp. 415-42.

Ehlermann, Claus-Dieter, "Role of the European Commission as Regards National Energy Policies", Journal of Energy \& Natural Resources Law, 12:3, pp. 342-353.

Goldthau, Andreas and Sitter, Nick, "A liberal actor in a realist world? The Commission and the external dimension of the single market for energy", Journal of European Public Policy, Vol. 21, No. 10, 2014, pp. 1452-1472.

Hancher, Leigh and Marhold, Anna, "A common EU framework regulating import pipelines for gas? Exploring the Commission's proposal to amend the 2009 Gas Directive", Journal of Energy \& Natural Resources Law, Vol. 37, Issue 3, 2019, pp. 289-303.

Herranz-Surrallés, Anna, Solorio, Israel and Fairbrass, Jenny, "Renegotiating authority in the Energy Union: A Framework for Analysis", Journal of European Integration, Vol. 42, No. 1, 2020, pp. 1-17.

Herveg, Nicole, European Union Policy-Making: The Regulatory Shift in Natural Gas Market Policy, International Series on Public Policy, Palgrave Macmillan, 2017.

Kingdon, W. John, Agendas, alternatives, and public policies, Boston: Little, Brown, 1984.

Maltby, Tomas, "European Union energy policy integration: A case of European Commission policy entrepreneurship and increasing supranationalism", Energy Policy, 55, 2013, pp. 435-444.

McGowan, Francis, "Can the European Union's Market Liberalism Ensure Energy Security in a Time of 'Economic Nationalism'?", Journal of Contemporary European Research, Vol. 4, No. 2, pp. 90-106.

Mišík, Matúš, External Energy Security in the European Union: Small Member States' Perspective, Routledge Advances in European Politics, Taylor \& Francis Inc, Bosa Roca, 2019.

Slot Piet, Jan and Skudder, Andrew, "Common features of community law regulation in the network-bound sectors", Common Market Law Review, 38, 2001, pp. 87-129. 
Evropsko zakonodavstvo, br. 75/2021

Stern, P. Jonathan, Competition and Liberalization in European Gas Markets: a Diversity of Models, Royal Institute of International Affairs, London, Washington D.C.: Brookings Institution, 1998.

Šekarić, Nevena, „Evropska energetska bezbednost: slučaj Severnog toka 2”, Međunarodna politika, br. 1179-80, 2020, str. 119-138.

Šekarić, Nevena, „Sekuritizacija energetskih odnosa između Evropske unije i Rusije: evropska perspektiva", Međunarodna politika, br. 1176, 2019, pp. 63-82.

Talus, Kim, Introduction to EU Energy Law, Oxford University Press, Oxford, 2016.

The Internal Energy Market, Commission Working Document, Commission of the European Communities, COM (88) 238 Final, Brussels, 2 May 1988.

Tubić, Bojan, „Međunarodna pravila o određivanju granica na moru”, Zbornik radova Pravnog fakulteta u Novom Sadu, 4, 2013, str. 337-352;

Vukčević, Dejana i Stojadinović, Miša, „Proces proširenja EU: koncept 'prelivanja”, Srpska politička misao, broj 4, Vol. 34, 2011, str. 131-152.

Winzer Christian, "Conceptualizing energy security", Energy policy, Vol. 46, 2012, pp. 36-48.

\section{(RE)POSITIONING OF THE EUROPEAN COMMISSION ON THE NATURAL GAS MARKET: FROM A LEADER OF ENERGY MARKET LIBERALIZATION TO THE “EUROPEAN REGULATOR”?}

Summary: This paper deals with the position of the European Commission on the natural gas market, in the period from the adoption of the First Energy Package to the adoption of the Third Energy Package. The aim of this paper is to analyse the role of the European Commission regarding the process of liberalization and integration of the natural gas market in the European Union. The methods used in this paper include the analysis of the acts contained in energy packages, but also the comparison of different legislative solutions in three energy packages. In that sense, the posed research question is whether the European Commission has become a new "European regulator" on the gas market, thanks to the powers granted to it by energy packages, especially the Third Energy Package. The conclusion of the research is that the legislator did not envisage assigning the role of energy regulator to the Commission, but granted it far-reaching powers - especially when deciding on the exemption of new energy infrastructure. The last part of the paper covers legislative changes initiated by the Commission, which go in the direction of expanding the scope of implementation of the Third Energy Package, thus further strengthening the Commission's position on the energy market.

Key words: European Commission, EC, energy market, natural gas market, liberalization, regulation, energy packages. 